\title{
LARS THOMAS
}

\section{DYRENE, DER IKKE BURDE EKSISTERE}

I det dunkle mørke lige uden for en gadelygtes lyskegle eller det flakkende skær fra et bål, findes en mystisk og skræmmende verden, der i hele menneskehedens historie har været befolket med en vrimmel af fantastiske væsener. Her svømmer havfruer om kap med søslanger, mens trolde og afskyelige snemænd lurer bag hvert eneste træ. De fleste af disse væsener er opdigtede fabeldyr, men visse ting peger på, at $\mathrm{i}$ det mindste nogle af dem er lyslevende, selvom det modsiger alt, hvad zoologibøgerne fortæller os. Det er dyrene, der ikke burde eksistere.

Videnskaben, der beskæftiger sig med den type dyr, kaldes kryptozoologi. Udtrykket kommer af det græske ord kryptos, der betyder skjult. Det er med andre ord læren om skjulte dyr. Udtrykket er opfundet af den fransk-belgiske zoolog Bernard Heuvelmans i 1950'erne (Heuvelmans 1995) og dækker studiet af tre forskellige grupper af dyr.

1. Velkendte arter, som iagttages på steder, hvor de ikke burde befinde sig. Det gælder for eksempel jyske pumaer eller fynske løver.

2. Dyr, der stadigt iagttages, selvom de officielt anses for at være uddøde. Den tasmanske pungulv er et glimrende eksempel, men også den centralafrikanske mokele-mbembe, der efter de indfødtes beskrivelser udviser stor lighed med en lyslevende dinosaurus, hører ind under denne gruppe.

3. Tilsyneladende ukendte dyrearter, som ikke er videnskabeligt beskrevet, men som kendes af lokalbefolkningen i bestemte områder, og som regelmæssigt iagttages. De bedst kendte eksempler er søslangen i den skotske sø Loch Ness og den afskyelige snemand i Himalaya.

Umiddelbart kunne man måske godt tro, at der på nuværende tidspunkt ikke er mulighed for at opdage flere nye, store dyr, men det er langtfra tilfældet. Bare inden for de sidste par år er der blevet opdaget mindst fire nye arter hjorte og okser i et relativt lille jungleområde i Vietnam (Timmins 1996). Der er plads til mange nye dyr endnu, og bare fordi en forsker ikke har fundet et eksemplar, er det ikke ensbetydende med, at det ikke eksisterer. Som de engelske forfattere Janet og Colin Bord så rammende har udtrykt det: „Mangel på bevis er ikke det samme som bevis på mangel“(Bord \& Bord 1989).

Kryptozoologi er en videnskab, der blander aspekter fra mange forskellige forskningsområder. Zoologi og folkemindevidenskab er de vigtigste, men også historiske, so- 
ciologiske, arkæologiske og psykologiske aspekter må tages i betragtning, når et dyrs eksistens skal vurderes.

Det kryptozoologiske arbejde drejer sig i de fleste tilfælde om at vurdere, om der ligger iagttagelser af reelle dyr eller naturfænomener til grund for de historier om mystiske dyr, som øjenvidner over hele jorden fortæller. Disse beretninger bliver meget sjældent taget alvorligt af klassiske zoologer, der anser dem for at være lige så virkelige, som middelalderens legender om enhjørninger. Mange zoologer glemmer dog at tænke på, at selv de mest fantastiske historier om fabeldyr er baseret på virkelige skabninger. Enhjørninger eksisterer ganske rigtigt ikke, men det gør det indiske næsehorn og de tre-fire forskellige antilopearter, der har fungeret som den hornede hests ophav (Thomas 1996). Kryptozoologiens dyr er måske nok nutidens svar på fabeldyrene, men alene af den grund må de have rod i virkeligheden. Det skal dog ikke være nogen hemmelighed, at kryptozoologien har været præget af en lang række svindelnumre, der bestemt ikke har højnet det saglige niveau, men siden 1981 har der eksisteret en international forening for kryptozoologer, The International Society of Cryptozoology (ISC), som har arbejdet hårdt på at højne standarden inden for den kryptozoologiske forskning. Foreningen er dog nu lukket på grund af pengemangel, og aktiviteterne bliver i stedet videreført af det engelske Center for Fortean Zoology (CFZ).

Skulle det endelig vise sig, at samtlige historier er løgn eller indbildning, så ville det i sig selv være et psykologisk fænomen, der nok var et nærmere studium værd.

\section{Forvildede katte og løsslupne kænguruer}

Der er ikke noget mærkeligt ved at få øje på en puma, mens man går en tur i en nordamerikansk skov, eller en kænguru, mens man kører ud over den australske bush. Hvis de samme dyr derimod bliver set i en jysk skov eller på en engelsk hede, kan man roligt gå ud fra, at der er et eller andet galt. Sådanne dyr, der for så vidt er velkendte nok, men som optræder på steder, hvor de absolut ikke burde befinde sig, udgør kryptozoologiens første og mindst mystiske gruppe. Her er meget sjældent nogen tvivl om, hvilke dyr man har med at gøre. Spørgsmålet er, hvor de kommer fra. Store kattedyr er de mest almindelige arter i denne gruppe. I kryptozoologiske kredse går de under betegnelsen ABC'ere (Alien Big Cats) (Thomas 1990). De hyppigst sete arter er pumaer, sorte pantere og løver. I Danmark har vi blandt andet haft jyske pumaer og fynske løver.

De bedst kendte, og bedst undersøgte ABC'ere, er de sydengelske Exmoor-uhyrer. De bliver set på og omkring Exmoor og Dartmoor, to store hedeområder i grevskabet Devon i det sydvestlige England. Det er store sorte eller brune katte, der som regel kun vækker opmærksomhed, når de forgriber sig på de lokale fåreavleres dyr. Ellers nøjes de med at skræmme livet af sene nattevandrere og -kørere.

Formentlig drejer det sig i såvel Exmoor-uhyrets som i de fleste andre tilfælde om dyr, der er undsluppet fra fangenskab. Af frygt for repressalier siger deres ejere ikke noget om det, og dyrene får på den måde en chance for at etablere sig i det fri. I Exmoorområdet har der med sikkerhed været mindst 3 pumaer i fangenskab, og de er alle tre tilsyneladende forsvundet sporløst fra deres ejere (Thomas 1992).

Det er dog interessant, at området er meget rigt på legender om andre mystiske og betydeligt mere spøgelsesagtige dyr, som dog alligevel minder meget om de store katte. 
Her fortælles nemlig utallige legender om sorte hunde. Store sorte bæster med lysende øjne og flammer ud af gabet, som løber rundt på vejene om natten og varsler død og ulykke for dem, som møder dem. Faktisk var det disse historier, som i sin tid inspirerede den engelske forfatter Arthur Conan Doyle til at skrive den berømte Sherlock Holmes-roman „Baskervilles Hund“. Går man tilbage i de skriftlige kilder, finder man da også, at der er en flydende overgang fra historier om sorte hunde til historier om sorte katte. Man kunne derfor godt fristes til at tro, at kattene var lige så ulegemlige som de sorte spøgelseshunde, men der er ingen tvivl om, at i det mindste nogle af dem er levende væsener af kød og blod. Der skal lidt mere end et spøgelse til i løbet af en enkelt nat at forvandle et voksent får til et løst skind og et afgnavet skelet med brækket hals (Brierly 1989).

\section{Dyrene, der nægter at dø}

Det bliver straks lidt mere mystisk, når man kommer ind på kryptozoologiens anden gruppe, nemlig de dyr, der officielt er erklæret uddøde, men som alligevel bliver set. Dyr fra denne gruppe har været meget brugt i spændingsromaner og underholdningsfilm. Det var formentlig Arthur Conan Doyle, som med sin roman „Den forsvundne verden“ var en af de første, der beskrev et mystisk sted, i dette tilfælde Roraima-plateauet i Sydamerika, hvor forskellige fortidsdyr, ikke mindst dinosaurer, stadigt levede i bedste velgående.

Mange zoologiske opdagelser, specielt fra dette århundrede, har da også vist, at et dyr kan leve ubemærket i millioner af år og derefter blive opdaget af mennesker ved et tilfælde. I 1938 fangede fiskere ud for kysten af Sydafrika således en stor blå fisk, der viste sig at høre til de såkaldte kvastfinnede fisk, en dyregruppe som dengang var velkendt, men kun i forstenet form. Man regnede på det tidspunkt med, at de kvastfinnede fisk var forsvundet for mindst 60-70 millioner år siden (Thomas 1987).

De to bedst kendte eksempler på disse dyr er den tasmanske pungulv, et hundestort rovpungdyr, der engang spillede den samme økologiske rolle i den australske natur, som ulven gør andre steder i verden, og den mystiske centralafrikanske mokele-mbembe, et dyr, der, hvis beskrivelserne af den tages for gode varer, må være en lyslevende dinosaurus.

\section{På sporet af pungulven}

I 1863, knapt 60 år efter opdagelsen af pungulven, udgav den engelske naturforsker John Gould første bind af sit store pragtværk „Mammals of Australia“. Heri findes en af de første beskrivelser af pungulvens liv, men samtidig også den første advarsel om, at den var truet af udryddelse:

Når den lille ø Tasmanien bliver tættere befolket, og dens uberørte skove er gennemskåret af veje fra øst- til vestkysten, vil antallet af dette specielle dyr hurtigt formindskes, udryddelsen vil få fuld magt, og det vil så, som ulven i England og Skotland blive nedskrevet som et dyr, der hører forgangne tider til. Selv om dette vil være en kilde til megen fortrydelse, kan hverken hyrden eller farmeren bebrejdes for at befri øen for et så besværligt væsen. Der er allerede sat en pris på tigerens hoved [pungulven gik også under navnet tasmansk tiger], men Tasmaniens klipper klædt med uigennemtrængelige skove vil, i hvert fald for øjeblikket, redde dyret fra ødelæggelse (Gould 1863). 
Det skulle snart vise sig, at John Gould havde ret i sin profeti. Pungulvens skæbne var et studie i tilbagegang fra opdagelsen til den 7. september 1936, hvor Benjamin, den sidste med sikkerhed kendte pungulv, døde i Hobart Zoo på Tasmanien.

Pungulven var engang almindelig i hele Australien og New Guinea, men forsvandt fra disse områder for mindst 2.000 år siden. Årsagen var formentlig en kombination af klimaændringer og konkurrence fra dingoen, den australske vildhund. Der har imidlertid aldrig levet dingoer på Tasmanien, så der må udryddelsen have en anden årsag.

Nu har pungulven dog aldrig været særlig almindelig. De første 27 år dyret var kendt, blev der, så vidt vides, kun skudt fire individer. I 1835 indførte regeringen så skydepræmier, og derefter tog jagten rigtig fart. Sidst i 1800-tallet var mere end 3.000 dyr blevet dræbt, og pungulven var blevet meget sjælden. Først i 1900-tallet brød bestanden helt sammen. En mystisk sygdom, sandsynligvis hundesyge, angreb både pungulven og den tasmanske pungdjævel, og bestanden faldt meget drastisk. Jagten har formentlig kun givet pungulven det sidste skub ud over afgrunden. Pungdjævelen kom sig derimod.

I 1909 blev der kun udbetalt 2 skydepræmier for pungulve, og i løbet af de næste 20 år forsvandt de totalt. Det var nærmest ironisk, at den australske regering i 1938, to år efter Benjamins død, besluttede sig for at frede pungulven (Guiler 1985).

Det er naturligvis svært at sige med sikkerhed, at en dyreart er udryddet, og der foretages da også stadig eftersøgninger efter pungulven. I de sidste 50 år er der blevet brugt over 1 million new zealandske dollars til efterforskningen, uden at det har frembragt ét eneste solidt bevis. Ikke desto mindre har over 800 mennesker siden 1936 påstået, at de har set lyslevende pungulve både på Tasmanien og, hvad der er betydeligt mere overraskende, på det australske fastland.

En meget stor del af disse beretninger kunne uden tvivl affærdiges som værende iagttagelser af hunde. Pungulven ser imidlertid så karakteristisk ud, at der ikke er megen tvivl om, at i det mindste nogle af beretningerne må være rigtige. Ekstra spændende er det også, at zoologer, der arbejder i New Guinea og i Irian Jaya, er i kontakt med indfødte, der påstår, at de også udmærket kender pungulven. Man ved, at den har levet i disse områder, men regner normalt med, at den er forsvundet derfra for mindst 2.000 år siden. Det kunne se ud til, at man har regnet forkert (Healey \& Cropper 1994).

\section{En levende dinosaur?}

Ifølge de indfødte i Likouala-området i de indre dele af den centralafrikanske stat Congo er områdets søer, floder og sumpe hjemsted for et meget usædvanligt dyr. Det har krop som en elefant, en lang hals og et ret lille hoved samt en lang hale, der bliver gradvis tyndere ud mod spidsen. Det ligner med andre ord en dinosaur. Dyret går under navnet mokele-mbembe, og selv om de indfødte godt ved, at det lever af planter, er de alligevel yderst bange for det. Det kan være meget aggressivt, og kan, hvis det bliver provokeret, med lethed få en kano til at kæntre. Det æder ikke de mennesker, som falder over bord, men slår dem ihjel med kraftige slag af sin lange hale.

Ingen ved med sikkerhed, hvor længe de indfødte har kendt dette dyr, men i den vestlige verden kender man iagttagelser, der går tilbage til i hvertfald 1913. Det år var en tysk ekspedition under ledelse af Friherre von Stein zu Lausnitz i færd med at udforske Congo, og i den forbindelse blev de første beretninger indsamlet. 
Trods mange fors $ø$ g og adskillige ekspeditioner til området er det endnu ikke lykkedes at få det endelige bevis på dyrets eksistens og identitet. De fleste zoologer er dog efterhånden enige om, at der lever et eller andet i Likouala-sumpene, som ikke uden videre lader sig forklare (Mackal 1987). På et vist tidspunkt troede mange, at det endelige bevis var inden for rækkevidde, da en af de indfødte fortalte om en landsby, hvor man havde fanget en mokele-mbembe og spist den. Desværre havde måltidet taget livet af samtlige deltagere, og ingen vidste, hvad der var blevet af dyrets knogler bagefter.

Det er umiddelbart svært at forestille sig, hvad en mokele-mbembe kan være, hvis det ikke er en levende dinosaur. Og der er da sådan set heller ikke noget i vejen for, at det kunne være tilfældet. Nyere forskning har efterhånden vist, at den katastrofeagtige uddøen, som man ellers har forklaret dinosaurernes forsvinden med, ikke har fundet sted (Hansen 1990). Derfor kunne enkelte arter godt have overlevet, og Centralafrika ville have været et glimrende sted for dem. Området er geologisk meget stabilt, og der er intet som tyder på, at klimaet har ændret sig ret meget gennem tiden. Det er en typisk „forsvunden verden,“ og man kan godt undre sig over, hvad der ellers gemmer sig i skovene og sumpene. De indfødte fortæller nemlig historier om flere andre mystiske dyr, som heller ikke findes i moderne zoologibøger (Shuker 1995).

\section{Fantasi eller virkelighed?}

Den sidste af de kryptozoologiske dyregrupper er langt den mest mystiske. Her finder man dyr, som slet ikke ligner nogle af dem, man kender i forvejen. Faktisk ser de mest ud til at være trådt lyslevende ud af et eventyr.

Mange af de fabeldyr, man har troet på i tidens løb, har for længst vist sig at være frit opfundne væsener, der er blevet til ved en sammensmeltning af historier om forskellige rigtige dyr. Men nogle af dem har også vist sig at være rigtige dyr. Og der er ikke spor i vejen for, at det også skulle gælde nogle af de søslanger, havuhyrer og andre mærkværdigheder, som udgør hovedparten af denne gruppe.

\section{En levende legende}

I sin bog om „Norges naturlige historie“ fra 1753 beskriver den norske biskop Erik Ludvigsen Pontoppidan mange af de fantastiske dyr, man efter sigende kan finde $\mathrm{i}$ havet omkring Norge, heriblandt ,det største havuhyre i verden. Det kaldes Kraken og er rundt, fladt og fuld af arme eller forgreninger." (Pontoppidan 1753). Ifølge Pontoppidan har de lokale fiskere et nært kendskab til kraken. Når de på en varm sommerdag ror ud til havs, sker det ofte, at der på steder, hvor vandet burde være flere hundrede meter dybt, tilsyneladende kun er 40-50 meter til bunden. Der er altid mange fisk disse steder, så fiskerne kan få en god fangst, men det er også farligt. Den gode fangst skyldes nemlig, at kraken er ved bunden. Hvis dybden pludselig bliver mindre, er det tid for fiskerne at hive deres liner ind hurtigst muligt. Så er kraken nemlig på vej op til overfladen, og så kan det være livsfarligt at opholde sig i nærheden. Når den endelig kommer op, viser den sig

først som et antal små øer omgivet af noget, der flyder og snor sig som tang. Til sidst duk- 
ker flere spidse tunger eller horn frem, der bliver tykkere og tykkere, jo højere de kommer op over vandoverfladen. Det er væsenets arme, og det siges, at de kan trække selv det største krigsskib ned til havets bund. Efter et stykke tid synker dyret ned igen, og så må fiskerne igen passe på, fordi deres både kan blive suget ned af de voldsomme hvirvler, som dyret frembringer på overfladen (Pontoppidan 1753).

Umiddelbart skulle man ikke tro, at dette fantastiske dyr havde noget som helst med virkeligheden at gøre, men det er ikke desto mindre tilfældet. Det var den danske zoolog Japetus Steenstrup, som i 1853 viste, at kraken i virkeligheden var en kæmpeblæksprutte. Det år skyllede en lille kraken nemlig op på stranden ved Ålbæk i Nordjylland, og så var der ikke så meget at være i tvivl om mere (Steenstrup 1855). Det eneste, de norske fiskere havde overdrevet i deres historier, var dyrets størrelse. Og det havde såmænd ikke engang været nødvendigt. Selv kæmpeblæksprutter af normal størrelse kan sagtens gøre sig fortjent til at blive kaldt uhyrer. I 1878 skyllede et eksemplar i land på kysten af New Foundland. Det målte næsten 18 meter.

En del mennesker havde dog stadig svært ved at tro på disse dyrs eksistens. Et medlem af det franske videnskabsakademi mente, at et sådant dyr var en umulighed, fordi „det ville modsige de love om harmoni og ligevægt, som dirigerer naturens mangfoldige frembringelser“ (Heuvelmans 1968).

\section{En mangfoldighed af havuhyrer}

Kryptozoologiens fader, den fransk-belgiske zoolog Bernard Heuvelmans, var den første, der lavede et dybdegående studie af de mange beretninger om havuhyrer, der kendes fra det meste af verden. Tidligere havde både den franske naturforsker Constantin Samuel Rafinesque (Rafinesque 1819) og den hollandske midespecialist Antoon Oudemans (Oudemans 1892) fors $ø \mathrm{gt}$ sig med at beskrive og klassificere havuhyrer, men de begik begge to en meget stor fejl, der gjorde det meget svært for andre videnskabsmænd at acceptere deres arbejde; de gik ud fra, at der kun fandtes én slags havuhyre, og at alle iagttagelser derfor måtte passe ind i en og samme form. Resultatet var, at man i hvert eneste tilfælde skulle bruge en masse tid og energi på at forklare alle de ting, som iagttageren ikke havde set.

Heuvelmans opdagede, at en meget stor del af disse problemer forsvandt, hvis man gik ud fra, at der eksisterede flere forskellige arter af havuhyrer. Efter en indgående analyse af flere hundrade iagttagelser nåede han så frem til, at der måtte eksistere mindst 9 forskellige typer eller med andre ord 9 arter af store havdyr, som ventede på videnskabelig anerkendelse og beskrivelse.

Detaljerede beskrivelser af havuhyrerne kan findes i Heuvelmans klassiske værk „In the Wake of the Sea-Serpents“ (1968): Her kan de ganske kort beskrives som:

1. Langhalsen. Stor kraftig krop, lang hals med et lille hoved, store veludviklede luffer. Længde: 5-20 m.

2. Havhesten. Stor kraftig krop, lang hals med et lille hoved og meget store øjne. En lang bølgende manke på halsen. Store veludviklede luffer. Længde: $10-30 \mathrm{~m}$.

3. Pukkeluhyret. Langstrakt krop med en række tydelige pukler ned langs ryggen. Kort, men tydelig hals med et hoved af form nogenlunde som en kos. To store luffer fortil og en bred hale. Længde: $20-35 \mathrm{~m}$. 
4. Finneuhyret. Langstrakt krop med en række fremspring eller finner på hver side. Kort hals og et ret lille hoved af form som en sæl. Længde: 10-30 m.

5. Superodderen. Meget langstrakt og slank krop. Lang hals med et lille hoved og meget lang hale. Fire tydelige luffer. Længde: 20-35 m.

6. Superålene. Meget langstrakt slangeformet krop. Ingen luffer og ingen halefinne. Varierer meget i udseende. Kan være flere forskellige arter. Længde: 10-30 m.

7. Havøglen. Krokodillelignende dyr. Længde: $15-20 \mathrm{~m}$.

8. Kæmpeskildpadden. Meget stort skildpaddelignende dyr. Længde: 10-15 m.

9. Gulbugen. Meget langstrakt havdyr formet som en haletudse, sædvanligvis meget kraftigt mønstret i sort og gul. Længde: 20-35 m.

Nummer 1 og 2 er formentlig sæler af en eller anden form, omend de er betydeligt større end selv de største sæler, vi kender til. 3 og 4 er sandsynligvis hvaler, og det samme gælder 5, selvom den i givet fald må være en meget primitiv hvaltype, som stammer helt tilbage fra den gang, hvalerne havde fire lemmer. Superålene er formentlig præcis, hvad deres navn antyder, kæmpestore fisk. Og både havøglen og kæmpeskildpadden må være krybdyr. Tilbage er der så gulbugen, der er stort set umulig at placere. Den er også kun blevet set ganske få gange, så de oplysninger, vi har om den, er yderst sparsomme (Heuvelmans 1968).

\section{Opskyl og strandvaskere}

For $ø$ jeblikket findes der ikke ét eneste bevis for, at havuhyrer virkelig eksisterer. De mange iagttagelser er godt nok konsistente, men der findes hverken billeder eller indsamlede eksemplarer af disse dyr. Af og til skyller der ganske vist store forrådnede dyr op på kysterne rundt omkring i verden, men de har i næsten alle tilfælde kunnet forklares med kendte dyr, især døde og stærkt forrådnede brugdehajer.

Det er straks sværere at forklare de såkaldte globsters. De er ikke meget andet end store klumper kød og spæk. De er blevet fundet så langt fra hinanden som Tasmanien og Bermuda. Ved første øjekast ligner de spækklumper fra hvaler, men de er ofte så hårde, at man dårligt kan skære i dem med en kniv, og da de meget sjældent indeholder knogler eller andre hårde dele, er det meget svært at bestemme deres identitet (Thomas 1991).

\section{Søslanger og søforklaringer}

Af de hundreder af søer verden over, som tilsyneladende rummer store, ukendte levende væsener, er ingen vel mere berømt end Skotlands Loch Ness. Beliggende i Glenmoredalen i det nordlige Skotland strækker den sig fra nordøst til sydvest tværs over landet. Det er Skotlands næststørste s $\emptyset, 42$ kilometer lang, men kun 3 kilometer bred på det bredeste sted. Søen er også meget dyb, næsten 300 meter på det dybeste sted og ellers med en gennemsnitsdybde på omkring 130 meter. Vandet er meget uklart, og solens stråler trænger sjældent mere end nogle få meter ned i søen. Alt i alt er det ikke det nemmeste sted i verden at finde et levende væsen. Der er dog masser af fisk i Loch Ness. Store laks og ørreder gør den til et yndet opholdssted for lystfiskere, og mængden af ål i søen er meget stor. 
Historien om Loch Ness-uhyret eller Nessie, som det populært kaldes, starter reelt i 1933, da dyret bliver forsidestof på alverdens aviser. Der findes dog også langt ældre beretninger end denne. Den tidligste er fra år $565 \mathrm{og}$ kan findes i levnedsbeskrivelsen af den irske helgen Sankt Columba, som det år havde et møde med uhyret i Loch Ness. Siden hen er der blevet indsamlet tusinder af beretninger om dyret, og der er sågar taget en stribe billeder og også enkelte filmstumper af et eller andet stort, der bevæger sig rundt ude i søen. Der eksisterer undervandsbilleder af noget stort forsynet med luffer dybt nede i søen, og fintmærkende sonarapparater har flere gange registreret store ,ting“, der bevæger sig rundt nede i vandet (Mackal 1976).

Det har været en stående vittighed blandt skeptikere i årevis, at Loch Ness-uhyret er opfundet af den skotske turistforening, fordi det trækker så mange mennesker til området, men det har ikke megen bund i virkeligheden. Historierne om Loch Ness-uhyret er langt ældre end noget turistbureau, og desuden forsøgte de lokale turistmyndigheder ved Loch Ness flere gange at smide de folk væk, der var på jagt efter søslangen.

Det største problem med Loch Ness-uhyret har ikke så meget været at se det, men at kunne give en fornuftig forklaring på, hvad dyret eller dyrene, for der må naturligvis være flere, i givet fald kunne være. Der er blevet fremsat et væld af teorier, men ingen af dem er i stand til at forklare alle de egenskaber, dyrene tilsyneladende er i besiddelse af. Det kunne tyde på, at vi stadig mangler nogle vigtige oplysninger, eller at det fænomen, vi kender som Loch Ness-uhyret, i virkeligheden ikke er et, men flere forskellige dyr, der er blevet blandet sammen til det færdige billede af et langhalset søuhyre.

\section{Big hairy monsters}

Store behårede uhyrer eller BHM'ere er den kryptozoologiske betegnelse for de store behårede abe- eller menneskelignende væsener, der tilsyneladende lever rundt om på Jorden i øde bjerg-, skov- eller ørkenområder. De kendes fra samtlige verdensdele, omend de to bedst kendte eksempler er yetien eller den afskyelige snemand fra Himalaya og den nordamerikanske Bigfoot eller Sasquatch.

Skovbestyrere, plantageledere og militærfolk var de første, som offentliggjorde beretninger om mystiske fodspor og indfødtes historier om de vilde mennesker, der fandtes rundt om i skovene og bjergene i Himalaya. Beretningerne tog imidlertid afgørende fart med den voldsomme bjergbestigningsaktivitet, der begyndte i løbet af 1900-tallet.

En af de mere berømte yeti-iagttagelser stammer fra grænsen mellem Nepal og Tibet i 1951. Her var Eric Shipton og Michael Ward, to medlemmer af en engelsk Mount Everest-ekspedition, i færd med at krydse Menlung-gletcheren, da de fandt en lang række fodspor. De to bjergbestigeres sherpaer identificerede sporene som afsat af to yetier. Men skønt sporene var meget friske, blev dyrene ikke set ved den lejlighed.

Yetier optræder almindeligvis uhyre fredeligt. I 1977 brød én ind i Peter Boardman og Joe Taskers lejr i 5000 meters højde på Cangabang i Himalaya. De to bjergbestigere blev vækket midt om natten ved, at deres kogegrej blev væltet, og en eller anden rumsterede rundt udenfor. Næste morgen fandt de $30 \mathrm{~cm}$ lange fodspor i sneen. Det eneste, der manglede, var en kasse med 36 plader chokolade (Bord \& Bord 1984).

Ud over Himalaya-området er det især i det vestlige Nordamerika, der er blevet set BHM'ere. Her går de som regel under navnet bigfoot eller Sasquatch. Den mest berømte 
iagttagelse stammer fra 1967, hvor der blev optaget en film af det mystiske væsen. Desværre har det ikke gjort sagen klarere. Trods utallige undersøgelser diskuterer kryptozoologer den dag i dag stadig, om det er en ægte eller en falsk iagttagelse.

Den 20. oktober 1967 var Roger Patterson og Bob Gimlin på hesteryg på vej til Bluff Creek-området $\mathrm{i}$ det nordlige Californien, hvor der flere gange tidligere var blevet fundet Bigfoot-spor. Idet de to mænd passerede et skarpt knæk på floden, begyndte deres heste at blive urolige og stejlede. Da Pattersons hest faldt, og han selv blev kastet af, fik han øje på grunden til hestenes skræk. På den anden flodbred, omkring 30 meter borte, stod en Bigfoot. Patterson greb sit kamera og begyndte at filme samtidigt med, at han løb nærmere. Filmen var noget rystet, men viste tydeligt et menneskelignende væsen, en hun, meget kraftigt bygget og med kort sort pels. Højden var over to meter, og at dømme efter dybden af fodaftrykkene, der senere blev undersøgt, må væsenet have vejet over $150 \mathrm{~kg}$. Selv om dyret tilsyneladende ikke var skræmt, forlod det alligevel hurtigt stedet. Det, der på filmen ser ud til at være afslappet gang, viste sig ved nærmere undersøgelser at bestå af skridt på over en meters længde (Bord \& Bord 1982).

Der er flere mulige forklaringer på disse dyr. Svindelnumre er altid en mulighed, men i langt de fleste tilfælde må dette udelukkes, fordi det ville have krævet meget store ressourcer at gennemføre. Muligheden for forveksling med allerede kendte dyr er naturligvis til stede, men er dog ret begrænset. De væsener, det drejer sig om, bevæger sig næsten kun på to ben, og det gør stort set kun mennesker og fugle.

I Nordamerika er bjørne den eneste reelle forvekslingsmulighed, men deres evne til at bevæge sig på to ben er meget begrænset. Det samme gælder i Asien, hvor også de allerede kendte aber må udelukkes, da de er betydeligt mindre end de omtalte væsener og $\mathrm{i}$ øvrigt også kun sjældent går på to ben.

Den sidste mulighed er eksistensen af nogle for videnskaben hidtil ukendte arter af højere primater. Tobenet gang og den kraftige udvikling af bryster, som det ses hos blandt andet dyret fra Bluff Creek, peger på et nært slægtskab til mennesker. Noget endegyldigt bevis er vi dog ikke i besiddelse af. Der er fundet enkelte ukendte hår rundt om, men de har kun kunnet vise, at der i de pågældende områder findes et dyr, der ikke er identisk med dem, man kender fra området i forvejen.

\section{Dyrene, der ikke burde eksistere}

Ud over de rent zoologiske problemstillinger, er der også mange interessante menneskelige aspekter forbundet med kryptozoologien. Det viser sig nemlig meget hurtigt, at alle mennesker har en mening om disse væsener. Store ukendte og lidt skræmmende dyr påvirker menneskers fantasi og psyke på en meget gennemgribende måde. Det er uhyre sjældent at møde mennesker, der er ligeglade med disse dyr. Enten tror de på deres eksistens, eller også er de sammenbidt skeptiske.

Et af de mest interessante aspekter er den ændring, der sker med dyrene og historierne om dem i takt med samfundets almindelige udvikling og de aktuelle begivenheder. Under Anden Verdenskrig var der for eksempel en påfaldende mangel på iagttagelser af søslanger i de store amerikanske og canadiske søer. Til gengæld påstod mange mennesker nu, at de havde set periskoperne af miniubåde, som blev afprøvet i søerne (Meurger \& Gagnon 1988). Da krigen stoppede, og frygten lagde sig hos folk, dukkede søslanger- 
ne op igen. Disse særprægede ændringer har fået de fleste zoologer til at stille sig meget skeptisk an i forhold til kryptozoologiens dyr.

\section{Skrækken for det nye}

Den engelske forfatter Lyall Watson skriver i sin bog „Neophilia“ (Watson 1989), at nysgerrigheden og trangen til at opleve nye ting er en af menneskehedens vigtigste drivkræfter. Det er uden tvivl rigtigt, men han glemmer den næsten lige så stærke „neofobi“, frygten for det nye, som kan forsinke fremskridt og bremse nye opdagelser $\mathrm{i}$ årtier. Denne indstilling er desværre udbredt blandt mange forskere, som åbenbart mener, at verden er så grundigt udforsket, at nye store dyr som Bigfoot og Nessie kun kan eksistere i folks fantasi. Det er naturligvis rigtigt, at der for mange af dyrenes vedkommende kun er indicier for deres eksistens, men sådan har det været for mange andre i dag velkendte dyr, indtil det første eksemplar blev nedlagt.

Det forstyrrer tilsyneladende de skeptiske forskeres verdensbillede for meget, hvis de skal til fuldstændigt at ændre deres opfattelse af dyrerigets opbygning. Når diskussion så falder på søslanger og andre mærkværdige dyr, har de oven i købet en tendens til at bruge smædekampagner i stedet for argumenter. Den amerikanske matematiker Martin Gardner, der er en af verdens førende skeptikere i relation til alt, hvad der bare lugter af at være „overnaturligt", er ikke engang bleg for at skrive, at han ,,anser det for spild af tid at bruge rationelle argumenter" i $i$ en diskussion med folk, der tror på eksistensen af telepati, mystiske dyr, biorytmer eller et hvilket som helst andet emne, der falder bare en anelse uden for de videnskabelige hovedstrømninger (Gardner 1983).

\section{Blæksprutternes forbandelse}

I 1821 fandt en gruppe tilfældigt forbipasserende en død mand på en gade i Paris. Han var fattigt klædt og stærkt udtæret, og det er tvivlsomt, om nogle af hans tidligere venner og kollegaer ville have genkendt Pierre Denys de Montfort, som i 1790'erne var en af Frankrigs mest entusiastiske naturforskere.

Han brugte megen tid på at snakke med hvalfangere, som fortalte ham om de enorme stumper af blækspruttearme, som de af og til fandt i munden eller maven på fangne kaskelothvaler. På det grundlag nåede Montfort frem til, at der måtte leve kæmpeblæksprutter i havet. Da han i 1802 beskrev dem i sin „Historie Naturelle des Mollusques“, blev han imidlertid mødt med hånlatter. Han blev beskyldt for at overdrive hvalfangernes beskrivelser og for i øvrigt at være alt for godtroende, når han kunne tage deres sømandshistorier alvorligt.

Montfort blev meget hurtigt til grin i hele Frankrig, hans øvrige værker blev behandlet med foragt, og andre naturforskere forsømte ingen lejlighed til at rakke ned på ham. På et vist tidspunkt begyndte der endda at cirkulere rygter om, at Montfort var blevet dømt til galejtjeneste for svindel, og senere at han skulle være blevet spærret inde som sindssyg. I løbet af meget kort tid forsvandt Denye de Montfort ud af offentlighedens søgelys. Den sidste del af sit liv levede han af at samle muslinge- og snegleskaller og sælge dem til parisiske handlende (Heuvelmans 1968). 
Da Montfort begyndte at interessere sig for kæmpeblæksprutter, havde datidens videnskabsmænd for længst afvist dyrets eksistens. Eventuelle beretninger var enten opspind eller fejltagelser. Folk, der påstod, de så disse dyr, blev stemplet som løgnere, og forskere, der som Montfort begyndte at studere dem, blev udstødt af det videnskabelige samfund.

Det er de færreste, der får så mange problemer som Montfort, men mange andre har i tidens løb fået at mærke, hvad det koster at fremsætte ideer, der ikke passer med det alment accepterede verdensbillede.

\section{Uvidende søfolk og andre tåber}

Den 6. august 1848 så kaptajnen og det meste af mandskabet på den engelske fregat ,Daedalus" et stort dyr komme svømmende forbi skibet i havet ud for Afrikas vestkyst. Dyret lignede hverken en sæl, en hval eller noget andet stort havdyr, som kaptajn M'Quhae eller hans mandskab før havde set. Den eneste konklusion, de kunne komme frem til, var, at de havde set et havuhyre (Heuvelmans 1968).

Deres interessante beretning blev dog ikke modtaget med den begejstring, de havde forestillet sig, da de gik i land i Plymouth den 4. oktober. Sir Richard Owen, en af datidens førende videnskabsmænd, en berømt anatom og kurator ved Hunterian Museum, startede et regulært korstog mod havuhyrer af enhver art i almindelighed, og mod Daedalus-uhyret i særdeleshed. Owen var dengang 45 år gammel og havde et ualmindeligt godt og i det store hele velfortjent ry. Desværre var det steget ham til hovedet. Han opfattede sig selv som den absolutte autoritet inden for zoologien, og han brugte sin anseelse fuldstændigt skamløst til at afgøre eventuelle stridsspørgsmål på den mest kategoriske måde. Elleve år senere blev han også en af Charles Darwins argeste modstandere, da denne udgav „Arternes Oprindelse“ (Heuvelmans 1968).

I et brev til The Times skrev han, at det naturligvis måtte være en søelefant, folkene på „Daedalus“ havde set. Grunden til, at ingen af søfolkene, hvoraf flere havde en 40 års lang karriere bag sig, genkendte dyret, var at ,ingen om bord på Daedalus nogensinde havde set en stor sæl svømme i det åbne hav“ (Heuvelmans 1968). Owens grundlæggende opfattelse var, at man ikke kunne regne med øjenvidnebeskrivelser, med mindre de var lavet af folk med en naturvidenskabelig uddannelse, og så kunne man endda ikke engang være sikker.

En anden uheldig sjæI var naturforskeren Constantin Samuel Rafinesque-Schmaltz, som i 1817 udgav en videnskabelig beskrivelse af et havuhyre, som flere år i træk hver sommer havde holdt til i havet ud for Gloucester i Massachusetts. Flere tusind mennesker havde set dyret, men det var alligevel ikke nok til at få et eneste medlem af Linnean Society i New York til at rejse til Gloucester for at se dyret med egne øjne. Rafinesque var villig til at tro de mange øjenvidner, men det havde nær ødelagt hans karriere. Han blev smidt ud fra det universitet, han arbejdede på, og var tæt ved at blive erklæret sindssyg. For at undgå videre problemer rejste han til USA, hvor han blev en højt agtet forsker. Han beskrev blandt andet flere tusind nye arter, hvoraf de fleste anerkendes den dag i dag (Heuvelmans 1968).

Et moderne eksempel på de akademiske problemer, som en aktiv interesse for kryptozoologi kan medføre, er den amerikanske antropolog Grover Krantz, der i mange år har studeret den amerikanske Bigfoot, Nordamerikas svar på den afskyelige snemand. På 
trods af at han har publiceret et meget stort antal afhandlinger inden for ,almindelig“ antropologi, er hans karriere gået betydeligt langsommere fremad end mindre aktive kollegers. Krantz er selv ikke i tvivl om, at det er hans Bigfoot-studier, der på en eller anden måde har gjort ham utroværdig (Krantz 1992).

\section{Gale svindlere og andet godtfolk}

På den anden side er det heller ikke underligt, at mange forskere er yderst skeptiske over for kryptozoologien. Området har været præget af svindelnumre af mange forskellige formater og udformninger, men også af hyperfølsomme, nærmest paranoide tilhængere, der har haft uendelig svært ved at tåle den mindste form for kritik. Det har gjort de fleste diskussioner totalt formålsløse og har mindsket de fleste forskeres lyst til at beskæftige sig med noget, der i deres øjne ser ud til at være spild af tid, penge og videnskabelig anseelse.

Man skal dog også passe på ikke at blive for forsigtig. Selvom de fleste nye ideer er ubrugelige, er det dog også blandt dem, man finder råmaterialet til nye forskningsområder. Ved at stemple én ide som tåbelig kan man også nemt komme til at blokere for andre frugtbare områder, der på en eller anden måde er forbundet med den.

Det har blandt andet betydet, at den skotske sø Loch Ness, som indeholder mere vand end nogen anden sø i Storbritanien, er en af de dårligst kendte søer på de Britiske Øer. Ferskvandsbiologer har simpelthen ikke turdet beskæftige sig med søen af frygt for at blive beskyldt for at være på jagt efter Loch Ness-uhyret (Witchell 1989). Først med Projekt Urquhart i begyndelsen af 1990'erne er man begyndt at se nærmere på et af de vigtigste ferskvandsområder i hele Nordvesteuropa (Thomas 1993).

\section{Det er zoologi det hele}

Et af problemerne med kryptozoologiens noget blakkede rygte er måske i virkeligheden ordet krypto-. Da Bernard Heuvelmans opfandt udtrykket, gjorde han måske alle zoologer en bjørnetjeneste ved at splitte dem op i to så adskilte grupper. I bund og grund er det jo zoologi det hele. For 100, 200 eller 300 år siden, var det også indfødtes historier, der ledte naturforskere og opdagelsesrejsende på sporet af tusinder af nye dyrearter. Alt for mange skeptiske zoologer har åbenbart glemt, at store dele af den ,seriøse“ zoologi, de arbejder med, hviler på et grundlag, som er opbygget af folk, der var villige til at lytte til historier om dyr, der ikke burde eksistere.

\section{Litteratur}

Bord, Janet \& Colin Bord

1982 The Bigfoot Casebook. London: Granada.

1984 The Evidence for Bigfoot and Other Man-beasts. Wellingborough: The Aquarian Press.

1989 Modern mysteries of the world. London: Grafton.

Brierly, Nigel

1989 They stalk by night. Bishops Nympton: Yeo Valley Productions. 
Costello, Peter

1974 In search of lake monsters. New York: Coward, McCann \& Geoghegan.

Gardner, Martin

1983 Science - Good, bad and bogus. Oxford: Oxford University Press.

Gould, John

1863 Mammals of Australia. London: John Gould.

Guiler, Eric R.

1985 Thylacine: The Tragedy of the Tasmanien Tiger. Melbourne: Oxford University Press.

Hansen, Hans Jørgen

1990 Diachronous extinctions at the K/T boundary, a scenario. Geological Society of America, Special paper 247: 417-23.

Healey, Tony \& Paul Cropper

$1994 \quad$ Out of the shadows. Chippendale: Ironbark.

Heuvelmans, Bernard

1968 In the Wake of the Sea-serpents. London: Hill \& Wang.

1995 On the track of unknown animals. London: Kegan Paul.

Krantz, Grover S.

1992 Big Footprints. Boulder: Johnson Books.

Mackal, Roy P.

1976 The Monsters of Loch Ness. London: Macdonald and Jane's.

1987 A Living Dinosaur? Leiden: E.J.Brill.

Meurger, Michel \& Claude Gagnon

1988 Lake Monster Traditions. London: Fortean Tomes.

Oudemans, A.C.

1892 The great sea-serpent. Leiden: E.J.Brill.

Pontoppidan, E.L.

1753 Det første forsøg paa Norges naturlige Historie. Kjoebenhavn.

Rafinesque, C.S.

1819 Dissertation on water-snakes, sea-snakes and sea-serpents. Philosophical Magazine 54

Shuker, Karl P.N.

1995 In search of prehistoric survivors. London: Blandford.

Steenstrup, J.J.

1855 Referat af Beskrivelse af et par Kjæber af en kolossal Blæksprutte. Overs.danske

Vidensk.Selsk.Forh.1855: 199-200.

Thomas, Lars

1987 Fantasi og virkelighed i naturen. Hillerød: Liberdan.

1990 Sære dyr og mærkelige væsener. København: Andersen Bogservice.

1991 Globs, døde hvaler og rådne hajer. UFO-Nyt 1: 19-21.

1992 Jagten på Exmoor-uhyret. København: Andersen Bogservice.

1993 Nu vil forskerne trænge til bunds i Loch Ness. Illustreret Videnskab 8, 1993.

1996 Mysteriet om enhjørningen og andre fabeldyr. København: Gyldendal.

Timmins, Robert

1996 Another muntjac materialises. BBC Wildlife 14(3): 22-23

Watson, Lyall

1989 Neophilia. London: Sceptre.

Witchell, Nicholas

1989 The Loch Ness Story. London: Corgi Books. 
